\title{
Bovine meat and bone meal is an economically viable alternative in quail feeding in the initial phase
}

\author{
CARLA C. PIZZOLANTE ${ }^{1}$, SÉRGIO K. KAKIMOTO ${ }^{2}$, JOSÉ E. MORAES ${ }^{1}$, ANA PAULA O. \\ SACCOMANI ${ }^{3}$, DANIELA F. SOARES ${ }^{3}$, GUSTAVO C. PASCHOALIN ${ }^{3}$ and FÁBIO E.L. BUDIÑO ${ }^{1}$ \\ ${ }^{1}$ Instituto de Zootecnia, Agência Paulista de Tecnologia dos Agronegócios/APTA, Secretaria de Agricultura e Abastecimento \\ do Estado de São Paulo/SAA, Rua Heitor Penteado, 56, Caixa Postal 60, 13460-000 Nova Odessa, SP, Brasil \\ ${ }^{2}$ Granja Kakimoto, Estrada Seção Cascata, Km 7, Seção Cascata, 17690-000 Bastos, SP, Brasil \\ ${ }^{3}$ Programa de Pós-Graduação em Produção Animal Sustentável, Instituto de Zootecnia, Agência \\ Paulista de Tecnologia dos Agronegócios, Secretaria de Agricultura e Abastecimento do Estado de \\ São Paulo, Rua Heitor Penteado, 56, Caixa Postal 60, 13460-000 Nova Odessa, SP, Brasil
}

Manuscript received on February 25, 2015; accepted for publication on April 10, 2015

\begin{abstract}
Quail egg production has experienced a steep rise in the last decade. Nutrition is the main factor affecting productive potential in the poultry industry, as appropriate nutritional management is necessary to ensure the maintenance of optimal physical conditions, growth and the production of high quality products. Meat and bone meal (MBM) has often been used in the poultry industry as an alternative and cost-effective source of protein in partial replacement of corn and soybean meal. However, there have been no studies to date that have investigated the effect of dietary MBM on the performance of quail or on the costs of production in the starter phase. This is particularly important considering that this phase is characterized by large investments by producers, without immediate economic return. In this study, we investigated whether partial replacement of soybean meal (SBM) by meat and bone meal (MBM) in the diet of Japanese quail during the starter phase is a viable alternative that would maintain or improve their productive and economic performance. Our results show that the inclusion of MBM in the diet of quail reduces feeding costs by up to $6 \%$ without impairing productive performance.
\end{abstract}

Key words: alternative feed, costs, levels, performance, protein feed.

\section{INTRODUCTION}

Quail egg production has experienced a steep rise in the last decade. Fast growth rates, early sexual maturity, high longevity and lower production costs compared to those of laying hens are all contributing factors to this trend (Pastore et al. 2012).

Correspondence to: Carla Cachoni Pizzolante

E-mail: carla@iz.sp.gov.br
Nutrition is the main factor affecting productive potential in the poultry industry, as appropriate nutritional management is necessary to ensure the maintenance of optimal physical conditions, growth and the production of high quality products (Costa et al. 2010). However, because the price of feed is also the main determinant of production costs (approximately 70\% of overall production costs), the investigation of diets promoting high 
product quality at reduced cost has been a constant target of research (Embrapa Meio-Norte 2007).

Meat and bone meal(MBM) has often been used in the poultry industry as an alternative and costeffective source of protein in partial replacement of corn and soybean meal, the main raw materials used in bird diets. MBM (a byproduct of bovine meat production) is not only cheaper, but also a source of crude protein content (ranging from 35 to $55 \%$ ) as well as of calcium and high availability phosphorous. This is particularly important considering that phosphorous is the third limiting factor relative to the cost of feed formulations (Campestrini 2005). MBM has also been shown to improve odor, texture and palatability of diets when used within appropriate nutritional thresholds (Lessire et al. 1985, Martosiswoyo and Jensen 1988, Jensen 1991, Dale 1997).

Quail use corn and soybean meal energy similarly to broilers and laying hens. However, the nutritional requirements of quail are different (Silva et al. 2012), as their protein requirement is higher than that of broilers, resulting in a higher feeding cost per unit of product (Silva et al. 2012). Thus, partial replacement of corn and soybean meal by MBM in the diet of quail could be a viable mean of ensuring an appropriate diet at reduced cost. To our knowledge, however, there have been no studies to date that have investigated the effect of dietary MBM on the performance of quail or on the costs of production in the starter phase. This is particularly important considering that this phase is characterized by large investments by producers, without immediate economic return. Ensuring appropriate development and growth during the starter phase is also critical for optimal productive performance in the long-term.

In this study we investigate whether partial replacement of soybean meal (SBM) by meat and bone meal (MBM) in the diet of Japanese quail during the starter phase is a viable alternative that would maintain or improve their productive and economic performance. Our results show that the inclusion of MBM in the diet of quail reduces feeding costs by up to $6 \%$ without impairing productive performance.

\section{MATERIALS AND METHODS}

The experiment was conducted in a poultry shed of the Agência Paulista de Tecnologia em Agronegócios, in Brotas, São Paulo, Brazil, in order to evaluate the effect of different levels of partial replacement of soybean meal (SBM) by meat and bone meal (MBM) in the diet of Japanese quail during the starter phase (1-35 days old). Seven hundred and twenty, 1-day-old quail were housed in a shed measuring $3.0 \times 12.0 \mathrm{~m}$, containing 24 boxes suitable for rearing at this stage. The $1.0 \mathrm{~m}^{2}$ boxes were equipped with feeders and waterers (pressure cup type). The quail, housed 30 per box, were heated with infrared lamps until 21 days of age in order to provide the proper temperature. The quail were subjected to identical conditions of management and feeding, with water and feed ad libitum. At seven days of age, the birds were vaccinated against Newcastle disease and at 21 days against fowlpox. The lighting program used was one of $23 \mathrm{~h}$ of light in the first week and then natural light until 35 days of age.

All procedures were carried out according to the international practices for animal use and care under the control of an internal committee of the Institute of Animal Science, São Paulo, Brazil.

The experimental design was completely randomized, with six experimental treatments, four replications and 30 animals per replication (Table I).

The experimental diets (Table II) were all isonutritive and formulated on the basis of corn and soybean meal as the raw materials, with levels of protein, calcium, phosphorus, metabolizable energy and amino acids established by Rostagno and Albino (2005) in order to meet the nutrient requirements of quail. 
TABLE I

Distribution of the experimental diets, using six levels of addition of bovine meat and bone meal (MBM) in the diets in place of soybean meal.

\begin{tabular}{cc}
\hline & \multicolumn{1}{c}{ Experimental Treatments } \\
\hline T1 (control) & Diet on the basis of corn, soybean meal and wheat $+0 \% \mathrm{MBM}$ \\
$\mathrm{T} 2$ & Diet on the basis of corn, soybean meal and wheat $+1 \% \mathrm{MBM}$ \\
$\mathrm{T} 3$ & Diet on the basis of corn, soybean meal and wheat $+2 \% \mathrm{MBM}$ \\
$\mathrm{T} 4$ & Diet on the basis of corn, soybean meal and wheat $+3 \% \mathrm{MBM}$ \\
$\mathrm{T} 5$ & Diet on the basis of corn, soybean meal and wheat $+4 \% \mathrm{MBM}$ \\
$\mathrm{T} 6$ & Diet on the basis of corn, soybean meal and wheat $+5 \% \mathrm{MBM}$ \\
\hline
\end{tabular}

TABLE II

Percent composition of feedstuffs and calculated nutrient levels of the experimental diets for Japanese quail during the starter period.

\begin{tabular}{|c|c|c|c|c|c|c|}
\hline \multirow{2}{*}{ Feedstuffs $(\%)$} & \multicolumn{6}{|c|}{ Experimental Diets } \\
\hline & $\mathrm{T} 1$ & $\mathrm{~T} 2$ & $\mathrm{~T} 3$ & $\mathrm{~T} 4$ & T5 & T6 \\
\hline Ground corn & 51.93 & 52.67 & 53.41 & 54.15 & 54.89 & 55.63 \\
\hline Soybean meal (45.5\%) & 42.07 & 41.06 & 40.04 & 39.03 & 38.02 & 37.00 \\
\hline Meat and bone meal & 0.00 & 1.00 & 2.00 & 3.00 & 4.00 & 5.00 \\
\hline Soybean oil & 2.28 & 2.05 & 1.82 & 1.59 & 1.36 & 1.13 \\
\hline Calcitic limestone $(38.4 \% \mathrm{Ca})$ & 0.866 & 0.738 & 0.610 & 0.481 & 0.353 & 0.225 \\
\hline Dicalcium phosphate & 1.864 & 1.504 & 1.145 & 0.785 & 0.425 & 0.066 \\
\hline Common salt & 0.398 & 0.387 & 0.376 & 0.366 & 0.355 & 0.344 \\
\hline Vitamin and mineral supplement $^{1}$ & 0.60 & 0.60 & 0.60 & 0.60 & 0.60 & 0.60 \\
\hline Total & 100 & 100 & 100 & 100 & 100 & 100 \\
\hline \multicolumn{7}{|l|}{ Nutrient Levels Calculated } \\
\hline Metabolizable energy (kcal/kg) & 2930 & 2930 & 2930 & 2930 & 2930 & 2930 \\
\hline Crude protein $(\%)$ & 23.50 & 23.50 & 23.50 & 23.50 & 23.50 & 23.50 \\
\hline Crude fiber $(\%)$ & 3.828 & 3.790 & 3.753 & 3.715 & 3.678 & 3.640 \\
\hline Calcium $(\%)$ & 0.980 & 0.980 & 0.980 & 0.980 & 0.980 & 0.980 \\
\hline Available phosphorus (\%) & 0.480 & 0.480 & 0.480 & 0.480 & 0.480 & 0.480 \\
\hline Methionine (\%) & 0.534 & 0.533 & 0.533 & 0.532 & 0.532 & 0.531 \\
\hline Methionine + Cystine (\%) & 0.906 & 0.903 & 0.901 & 0.898 & 0.895 & 0.892 \\
\hline Lysine (\%) & 1.323 & 1.315 & 1.306 & 1.298 & 1.289 & 1.280 \\
\hline
\end{tabular}

${ }^{1}$ Composition per kg of feed: Pantothenic acid 5,000.000 mg; Choline 43,400.000 mg; Niacin 6,680.000 mg; Vit. A 1,660,000.00 UI; Vit. B1 500,000 mg; Vit. B12 1,680.000 mg; Vit B2 1,000.000 mg; Vit. B6 666.700 mg; Vit. D3 208.400000 UI; Vit. E 3.360.000 mg; Vit. K3 500.000 mg; Cu 1,333.300 mg; Fe.8,33300 mg; I. 200.000 mg; Mn.11,666.600 mg; Zn. 8,333.300 mg; Se 33.330mg, Growth promoter 1,166.670 mg, Antioxidant 16,680.000 mg, q.s.p. carrier 1,000.000 g.

The MBM was analyzed bromatologically and contained $93.75 \%$ dry matter (DM), $45.75 \%$ crude protein $(\mathrm{CP}), 8.43 \%$ ether extract (EE), and $48.17 \%$ mineral matter (MM). MBM was added to the experimental diets according to the treatment used.

The production characteristics evaluated weekly, were weight gain (g), feed intake (g), feed conversion (FC) and mortality.
Statistical analysis by ANOVA and contrasts between treatment means by the Tukey test at 5\% were carried out with aid of the computer package Sisvar as described by Ferreira (2011). Economic performance was evaluated by using the price per kilogram of feed of each treatment, multiplied by the average amount of feed consumed by the quail until 35 days of age and added to the price of the 
quail. The values used were obtained by the site www.ovooline.com.br and www.iea.sp.gov.br of the Institute of Agricultural Economics (IEA) in September 2014.

\section{RESULTS AND DISCUSSION}

Minimum $\left(21.1{ }^{\circ} \mathrm{C}\right)$ and maximum $\left(27.8{ }^{\circ} \mathrm{C}\right)$ temperatures in the experimental shed were within the thermal comfort zone for Japanese quail in all treatments (Table III). There were, however, no significant differences $(\mathrm{p}>0.05)$ among treatments for any of the performance variables (Table III).

Our observation that the inclusion of MBM did not impair the performance of quail is consistent with a previous finding based on the use of this feed in partial replacement of corn and soybean meal in the diet of broilers (Bozkurt et al. 2004), where the authors observed no deleterious effect on either, performance or mortality. Similarly, Silva and Brandão (2011) have recently observed an increase in performance following the partial replacement of corn and soybean meal in the diet of quail during the starter phase. However, these authors used blood meal as the alternative feed source, as opposed to MBM. Our study is therefore the first to show that MBM can partially replace corn and soybean meal for quail during the starter phase without any impairment in performance - a finding still controversial in other bird production systems such as that of broilers (Faria Filho et al. 2002).

We also analyzed differences in the cost of the experimental diets, as measured per kilogram of feed and per bird (Table IV).

Our results showed the existence of economic benefits in formulating feed for quail during the

TABLE III

Performance of Japanese quail aged 1 to 35 days fed with diets with increasing proportion of meat and bone meal (MBM) in partial replacement of soybean meal.

\begin{tabular}{lcccccc}
\hline \multirow{2}{*}{ Treatments } & \multicolumn{7}{c}{ Performance (average) } \\
& $\mathrm{IBW}^{1}(\mathrm{~g})$ & $\mathrm{FBW}^{2}(\mathrm{~g})$ & $\mathrm{WG}^{3}(\mathrm{~g})$ & $\mathrm{FI}^{4}(\mathrm{~g})$ & $\mathrm{FC}^{5}$ & Mortality (\%) \\
\hline $0 \% \mathrm{MBM}$ & 7.02 & 132.77 & 122.54 & 426.73 & 3.43 & 0.4 \\
$1 \% \mathrm{MBM}$ & 7.28 & 128.91 & 119.18 & 411.84 & 3.39 & 0.3 \\
$2 \% \mathrm{MBM}$ & 7.18 & 131.52 & 122.87 & 427.44 & 3.47 & 0.5 \\
$3 \% \mathrm{MBM}$ & 7.14 & 126.70 & 118.86 & 405.19 & 3.40 & 0.2 \\
$4 \% \mathrm{MBM}$ & 7.08 & 128.27 & 116.80 & 416.53 & 3.45 & 0.9 \\
$5 \% \mathrm{MBM}$ & 7.13 & 126.47 & 118.18 & 415.12 & 3.50 & 0.2 \\
\hline Mean & 7.14 & 129.11 & 119.74 & 417.14 & 3.44 & 0.4 \\
$\mathrm{CV}(\%)$ & 3.57 & 2.24 & 2.99 & 4.39 & 4.43 & 79.25 \\
\hline
\end{tabular}

${ }^{1}$ Initial body weight, ${ }^{2}$ final body weight, ${ }^{3}$ weight gain, ${ }^{4}$ feed intake, ${ }^{5}$ feed conversion.

TABLE IV

Cost of diets (in US\$) with increasing proportions of meat and bone meal (MBM) in replacement of soybean meal fed to Japanese quail aged 1 to 35 days. Individual quail prices were the same for all diets (US\$ 0.192).

\begin{tabular}{lcccccc}
\hline & \multicolumn{5}{c}{ Treatments (\% MBM) } \\
& 0 & 1 & 2 & 3 & 4 & 5 \\
\hline Cost of diets (US\$ $/ \mathrm{kg}$ ) & 0.400 & 0.395 & 0.390 & 0.385 & 0.380 & 0.375 \\
\% of increase in cost relative to 5\% MBM & $6 \%$ & $5 \%$ & $4 \%$ & $3 \%$ & $1 \%$ & $0 \%$ \\
Diet cost/bird over the period (35 days) & 0.169 & 0.161 & 0.165 & 0.157 & 0.157 & 0.157 \\
\hline
\end{tabular}


initial phase with MBM in partial substitution of soybean meal, compared to feed formulated only with soybean meal as the main protein source. The results emphasize the notion that a reduction in the cost of food is closely related to the use of dietary nutrients, in this case effectively replacing soybean meal and dicalcium phosphate, which are the most expensive ingredients in the formulation of diets. Incorporation of MBM in the quail diet at a level of $3 \%$ resulted in an average reduction of up to $6 \%$ in the cost of feed, allowing savings of up to US\$0.00072/day/bird, or US\$0.026/bird over the 35 days comprising the starter period. For production plants with 25,000 to 150,000 birds, this could represent a saving of approximately US\$650 to US\$3,900 during this period.

It is possible to incorporate MBM as a replacement for soybean meal in starter phase diets for quail at levels as high as 5\% without loss in productive performance. Taking into account the price per bird and the individual cost of feed, this replacement represents savings of up to $6 \%$ of the diet cost during this phase.

\section{ACKNOWLEDGMENTS}

We would like to thanks Mr. Rocha from VICAMI, for donation of the quails and Kakimoto Farm for donation of feedstuffs and preparation of the diets used in this experiment. We are also grateful to Mr. Mizuma from Nutribastos, for donation of the vaccines and Mr. José Roberto Medina Garcia and Eduardo Piber Neto from BRNova who provided assistance with the laboratory analyses.

\section{RESUMO}

A produção de ovos de codorna tem experimentado um aumento acentuado na última década. A nutrição é o principal fator que afeta o potencial produtivo na indústria de aves, assim como o manejo nutricional adequado é necessário para garantir a manutenção das condições físicas ideais, crescimento e produção de produtos de alta qualidade. A farinha de carne e ossos
(FCO) tem sido frequentemente utilizada na indústria avícola como uma fonte alternativa e de baixo custo de proteína em substituição parcial do farelo de milho e soja. No entanto, até esta data, não houve estudos que tinham investigado o efeito da dieta FCO sobre o desempenho de codornas ou sobre os custos de produção na fase inicial de criação. Isto é particularmente importante tendo em vista que esta fase é caracterizada por grandes investimentos por parte dos produtores, sem retorno econômico imediato. Neste estudo, nós investigamos se a substituição parcial do farelo de soja (FS) por farinha de carne e ossos (FCO) na dieta de codornas japonesas durante a fase inicial de criação é uma alternativa viável que venha a manter ou melhorar o seu desempenho produtivo e econômico. Nossos resultados mostram que a inclusão da FCO na dieta de codornas reduz os custos de alimentação por até $6 \%$ sem prejudicar o desempenho produtivo.

Palavras-chave: alimentação alternativa, custos, níveis, performance, alimentos proteicos.

\section{REFERENCES}

BOZKURT M, BASMACIOGLU H AND ERGUL M. 2004. Effect of Dietary Concentration Meat and Bone Meal on Broiler Chickens Performance. Int J Poult Sci 3: 719-723.

CAMPESTRINI E. 2005. Farinha de carne e ossos. Revista Eletrônica Nutrime 24: 221-234.

COSTA CHR, BARRETO SLT, UMIGI RT, LIMA HJD, ARAUJO MS AND MEDINA P. 2010. Balanço de cálcio e fósforo e estudos dos níveis desses minerais em dietas para codornas japonesas (45 a 57 semanas de idade). Rev Bras Zootecn 39: 1748-1755.

DALE N. 1997. Metabolizable energy of meat and bone meal. J Appl Poultry Res 6: 169-173.

EMBRAPA MEIO-NORTE. 2007. Sistemas de produção. WebMD. Accessed Jan, 2015. http://sistemasdeproducao. cnptia.embrapa.br.

FARIA FILHO DE, FARIA DE, JUNQUEIRA OM, RIZZO MF, ARAUjo LF AND ARAÚJO CSS. 2002. Avaliação da Farinha de Carne e Ossos na Alimentação de Frangos de corte. Rev Bras Cienc Avíc 4(1): 1-9.

FERREIRA DF. 2011. Sisvar: a computer statistical analysis system. Ciênc Agrotec 35: 1039-1042.

JENSEN LS. 1991. Subproductos de animales em las formulaciones. Indust Avic 38: 28-31.

LESSIRE M, LECLERCQ B, CONAN L AND HALLOUIS JM. 1985. A methodological study of the relationship between the metabolizable energy values of two meat meals and their level of inclusion in the diet. Poult Sci 64: 1721-1728. 
MARTOSISWOYO AW AND JENSEN LS. 1988. Available energy in meat and bone meal as measured by different methods. Poult Sci 67: 280-293.

PASTORE SM, OLIVEIRA WP AND MUNIZ JCR. 2012. Panorama da coturnicultura no Brasil. Revista Eletrônica Nutritime 9: 2041-2049.

Rostagno HS AND AlBino LFT. 2005. II Simpósio Internacional Sobre Exigências Nutricionais de Aves e Suínos. Viçosa, MG - Brasil. 29 a 31 de Março, 2005.
SILVA DRP AND BRANDÃO PA. 2011. Desempenho produtivo de codornas (Coturnix coturnix) européias submetidas a níveis crescentes de farinha de sangue bovino. IX Congresso de Iniciação Científica da Universidade Federal de Campina Grande. Campina Grande, Paraíba, Brasil.

SILVA JHV, JORDÃO FILHO J, COSTA FGB, LACERDA PB, VARGAS DGV AND LIMA MR. 2012. Exigências nutricionais de codornas. Rev Bras Saúde Prod Anim, Salvador 13: 775-790. 